\title{
Effect of foreign capital on competition development in the European banking sector
}

\author{
Anatoliy Guley \\ Ph.D., Professor Bankovního institutu vysoké školy, Praha, the Czech Republic \\ Jaroslav Gusev \\ Ph.D., Director of the Bank branch, JSC VTB Bank (Ukraine), Ukraine
}

\begin{abstract}
This article explores the specific features of the functioning of foreign banking capital in the markets of the countries in the European Union. An analysis conducted to formalize the influence of the share of assets of foreign banks and banks under the control of a foreign investor in the assets of banking systems of 27 countries in the European Union on the level of competition allows one to assert that there is no single, clearly expressed tendency to influence this share on the level of competition. It has also been established that among 27 countries of the European union, two stable aggregates of countries can be identified, in banking systems of which the share of foreign bank capital practically did not change. It can be argued that the markets of the countries in the European Union, recipients of foreign banking capital, are exhausted from the point of view of further growth in the presence of foreign capital.
\end{abstract}

Keywords: banks, banking system, foreign capital, foreign investor, banks with foreign capital, foreign banks, foreign bank capital, a bank with a pseudo-foreign investor.

JEL Classification: G20, G21.

DOI: $10.21272 /$ fmir.1(2).71-79.2017.

(C) The Authors, 2017. This article is published with open access at ARMG Publishing.

\section{Introduction}

The internationalization of financial markets and the liberalization of trade in financial services exacerbated the problem of optimizing the macroeconomic parameters of the movement of foreign banking capital and its impact on the development of national economies of most countries in the world. During the global financial crisis, governments and regulators of the banking systems of these countries faced the problem of solving variously-directed issues: on the one hand, limiting the negative impact of the expansion of foreign banking capital on the level of financial stability of banking systems, and, on the other, protecting national financial markets from the consequences of a massive exit of banks with foreign capital under the influence of crisis phenomena.

\section{Literature review}

A great contribution to the development of scientific and methodological foundations of the rationale, methods and limits of the participation of foreign capital in the banking systems of various countries of the world was carried out by researchers from different countries. So D. J. Mathieson, J. Roldos [5] concluded that foreign ownership poses challenges for host countries due to the migration of decision-making and the incongruence of the organisational structures of foreign-owned banks and host country legal and regulatory systems. D. Morgan and P. Strahan [6] show empirically that bank integration across U.S. states over the late 1970s and 1980 dampened economic volatility within states. Internationally, however, we find that foreign bank integration, which advanced widely during the 1990s, has been either unrelated to volatility of firm investment spending or positively related to that volatility. The results suggest the possibility that business spending may become more volatile as countries open their banking sectors to foreign entry. M. Peria, M. Soledad and A. Mody [7] analyze the impact of increasing foreign participation and high concentration levels on Latin American bank spreads during the late 1990s, their results suggest that foreign banks were able to charge lower spreads relative to domestic banks. The overall level of foreign bank participation seemed to influence spreads indirectly, primarily through its effect on administrative costs. Bank concentration was positively and directly related to both higher spreads and costs. H. Schulz [8] found that the key contribution of foreign banks was the recapitalization of the banking sector following the financial crisis. But there is only limited evidence that banking sector efficiency 
increased as result of a transfer of skills, technology, or management know-how. The main reason for the limited impact of FDI was the low level of competitive intensity in the Mexican banking sector.

\section{Methods of research and findings}

The internationalization of economic relations, the liberalization of the trade in financial services and the integration processes in the world economy have intensified the processes of moving foreign banking capital beyond national borders, and created the basis for accelerating the processes of financial globalization.

Speaking about the level of the presence of foreign capital in the banking system, we consider it inexpedient to measure it only on the basis of the relative weight of foreign capital in the structure of banks' own capital. In our opinion, the most adequate indicator will characterize the level of the presence of foreign capital in the banking system, there will be a ratio of assets of banks with foreign capital to total assets of banks. As for the upper limit of this indicator, which will testify to the inactive interference of banks with foreign capital into competition, we believe that it is best to reflect the ratio of the country's foreign trade turnover to its GDP.

The process of migration of banking capital in the countries of the European Union began long ago and today there is practically no active expansion. Some fluctuations in the share of foreign capital are observed, but they are explained by the more tactical interests of large transnational banks. In general, if you analyze the assets of banks with foreign capital in European countries, it should be noted that in general, the specific weight of the European Union is small - at the level of 16-19\% [2]. It is also worth highlighting the countries in which there are almost no national banks left. They are Bulgaria, Estonia, Latvia, Luxembourg, Malta, Romania, Slovenia, Finland and the Czech Republic. It should be noted that in Europe there are also countries in which foreign capital in the banking system is practically absent, primarily Germany, France, Sweden, Italy and Spain. We can conclude that these five countries with a low share of assets in banks with foreign capital are the main donors of foreign capital to other countries in Europe (they can also be added to the UK, but in the last 3 years a fairly large share of bank capital in this country was bought out by foreign investors, mainly from Arab countries). That is, in this case there is an expansion of banking capital from more developed countries to less developed ones, which leads to the adoption of traditions and rules of competition in the corresponding direction. Confirmation of this is shown in Figure 1.

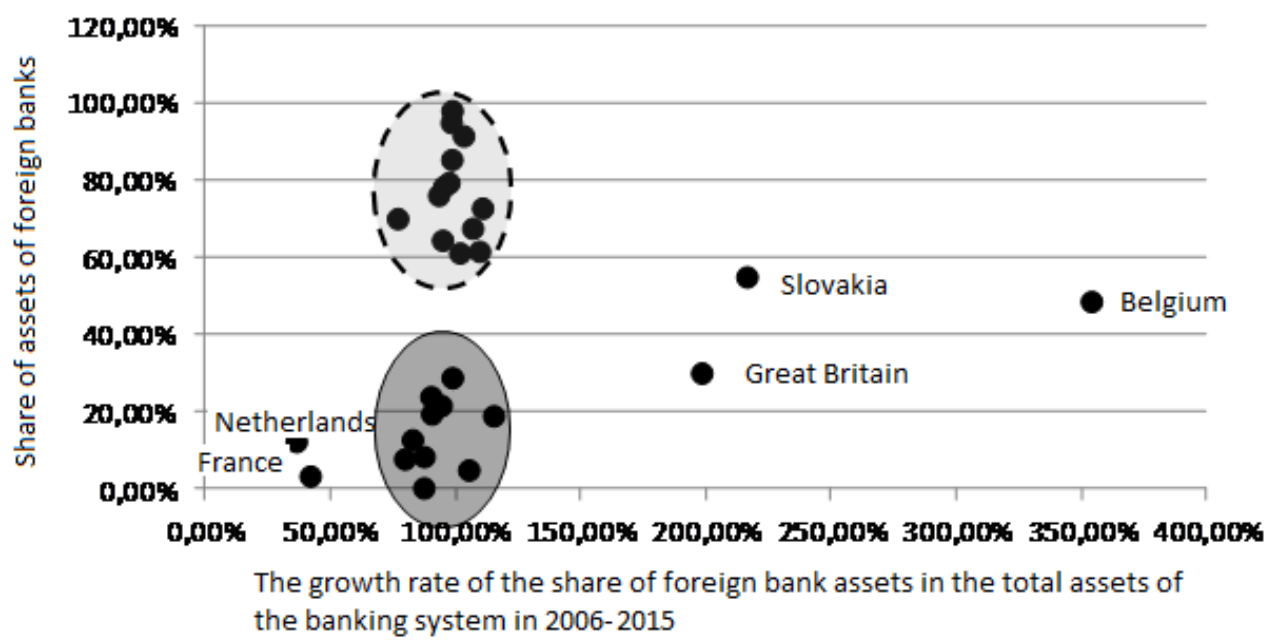

Figure 1. Expansion of foreign capital in European countries during 2006-2015

Source: compiled by authors.

As you can see, two stable zones of European countries can be clearly distinguished. The first zone includes countries with a relatively low share of foreign capital (from 0 to 30\%) - these are the donor countries of foreign capital (10 countries), the second zone is formed by recipient countries of foreign capital (13 countries). As in the first and the second zone, there are insignificant fluctuations in the share of assets of banks with foreign capital during the period under study, is the stabilization of the zones identified by us. 5 countries are characterized by high volatility of foreign banking capital, 3 of which (France, the Netherlands and the United Kingdom) have a relatively low share of banks with foreign capital, and 2 others (Belgium and Slovakia) - high. Due to the high volatility of the banking capital movement in these countries, we can not attribute them to the stable zones we have identified. 
The analysis showed that it is possible that the capital is exported from less developed countries in the more developed in such a case, the influence of competitive processes in the market of banking services of the country of the parent bank on interbank competition in the host country will be minimal, rather, it will borrow certain methods, tools, products, methods of the parent bank in their daughters, for their application in the banking market of the parent bank. Therefore, it can be noted that despite some sharp fluctuations in the share of foreign capital in the banking systems of individual European countries, on the whole, its share is steadily growing. To analyze the influence of foreign capital on competition in the banking sector, we will analyze the level of concentration of assets in the banking systems of European countries (Table 1). To estimate the concentration level, we use the Herfindahl-Hirschman index.

Table 1. Herfindahl-Hirschman Index for bank assets in European countries during 2009-2015

\begin{tabular}{|c|c|c|c|c|c|c|c|}
\hline \multirow[b]{2}{*}{ Country } & \multicolumn{7}{|c|}{ Years } \\
\hline & 2009 & 2010 & 2011 & 2012 & 2013 & 2014 & 2015 \\
\hline Austria & 0.0552 & 0.0560 & 0.0534 & 0.0527 & 0.0454 & 0.0414 & 0.0383 \\
\hline Belgium & 0.2102 & 0.2112 & 0.2041 & 0.2079 & 0.1881 & 0.1622 & 0.1439 \\
\hline Bulgaria & 0.0721 & 0.0698 & 0.0707 & 0.0833 & 0.0834 & 0.0846 & 0.0789 \\
\hline United Kingdom & 0.0376 & 0.0399 & 0.0394 & 0.0449 & 0.0412 & 0.0467 & 0.0522 \\
\hline Greece & 0.1070 & 0.1096 & 0.1101 & 0.1096 & 0.1172 & 0.1184 & 0.1214 \\
\hline Denmark & 0.1146 & 0.1115 & 0.1071 & 0.1120 & 0.1229 & 0.1042 & 0.1077 \\
\hline Estonia & 0.3887 & 0.4039 & 0.3593 & 0.3410 & 0.3120 & 0.3090 & 0.2929 \\
\hline Ireland & 0.0600 & 0.0600 & 0.0600 & 0.0700 & 0.0800 & 0.0900 & 0.0900 \\
\hline Spain & 0.0482 & 0.0487 & 0.0442 & 0.0459 & 0.0497 & 0.0507 & 0.0528 \\
\hline Italy & 0.0230 & 0.0230 & 0.0220 & 0.0328 & 0.0307 & 0.0298 & 0.0395 \\
\hline Cyprus & 0.0940 & 0.1029 & 0.1056 & 0.1089 & 0.1019 & 0.1089 & 0.1170 \\
\hline Latvia & 0.1021 & 0.1176 & 0.1271 & 0.1158 & 0.1205 & 0.1181 & 0.1005 \\
\hline Lithuania & 0.1854 & 0.1838 & 0.1913 & 0.1827 & 0.1714 & 0.1693 & 0.1545 \\
\hline Luxembourg & 0.0369 & 0.0373 & 0.0333 & 0.0316 & 0.0309 & 0.0310 & 0.0343 \\
\hline Malta & 0.1452 & 0.1330 & 0.1171 & 0.1177 & 0.1236 & 0.1250 & 0.1180 \\
\hline Netherlands & 0.1726 & 0.1796 & 0.1822 & 0.1928 & 0.2168 & 0.2032 & 0.2052 \\
\hline Germany & 0.0178 & 0.0174 & 0.0178 & 0.0183 & 0.0191 & 0.0206 & 0.0298 \\
\hline Poland & 0.0692 & 0.0650 & 0.0599 & 0.0640 & 0.0562 & 0.0574 & 0.0559 \\
\hline Portugal & 0.1093 & 0.1154 & 0.1134 & 0.1098 & 0.1114 & 0.1150 & 0.1203 \\
\hline Romania & 0.1111 & 0.1115 & 0.1165 & 0.1041 & 0.0922 & 0.0857 & 0.0871 \\
\hline Slovakia & 0.1154 & 0.1076 & 0.1131 & 0.1082 & 0.1197 & 0.1273 & 0.1239 \\
\hline Slovenia & 0.1425 & 0.1369 & 0.1300 & 0.1282 & 0.1268 & 0.1256 & 0.1160 \\
\hline Hungary & 0.0798 & 0.0795 & 0.0823 & 0.0840 & 0.0819 & 0.0864 & 0.0806 \\
\hline Finland & 0.2680 & 0.2730 & 0.2560 & 0.2540 & 0.3160 & 0.3120 & 0.3550 \\
\hline France & 0.0623 & 0.0727 & 0.0726 & 0.0679 & 0.0681 & 0.0605 & 0.0610 \\
\hline Czech Republic & 0.1103 & 0.1155 & 0.1104 & 0.1100 & 0.1014 & 0.1032 & 0.1042 \\
\hline Sweden & 0.0854 & 0.0845 & 0.0856 & 0.0934 & 0.0953 & 0.0899 & 0.0860 \\
\hline European Union, average meaning & 0.1120 & 0.1136 & 0.1105 & 0.1108 & 0.1120 & 0.1102 & 0.1099 \\
\hline
\end{tabular}

In general, for European countries, it is possible to establish a limiting level of concentration of banking assets (at the level of 10\%) with a slight excess, but many countries are characterized by a high level of concentration, such countries as Belgium, Greece, Denmark, Estonia, Cyprus, Latvia, Malta, the Netherlands, Portugal, Slovakia, Slovenia, Finland and the Czech Republic. At the same time, in Estonia, the Netherlands and Finland, the Herfindahl-Hirschman index exceeded 0.2, which indicates a low level of competition in the banking markets of these countries. Comparing these data with the data on the relative weight of foreign capital, it can be seen that in Estonia and Finland, banks are overwhelmingly foreign. As for the dynamics of the level of concentration of bank assets, in general for European countries it remained at a constant level, fluctuating within 0.1136-0.1099, however some countries are characterized by significant changes. For example, in Belgium for the period from 2009. By 2015, the Herfindahl-Hirschman index fell from 0.2102 to 0.1439 , in Estonia from 0.3887 to 0.2929 . In contrast, in the Netherlands, this indicator rose from 0.17 .26 to 0.2052 . I would like to note that the countries-exporters of bank capital defined by us above are characterized by a rather high level of competition, as evidenced by the low values of the Herfindahl-Hirschman index in these 
countries for the period under study. This may be an indirect evidence that a high share of foreign capital in the country's banking system leads to an increase in the concentration of bank assets, and as a result - to a decrease in competition. Despite this, it is impossible to single out the stable zones of interdependence of concentration and the share of assets of banks with foreign capital (Figure 2).

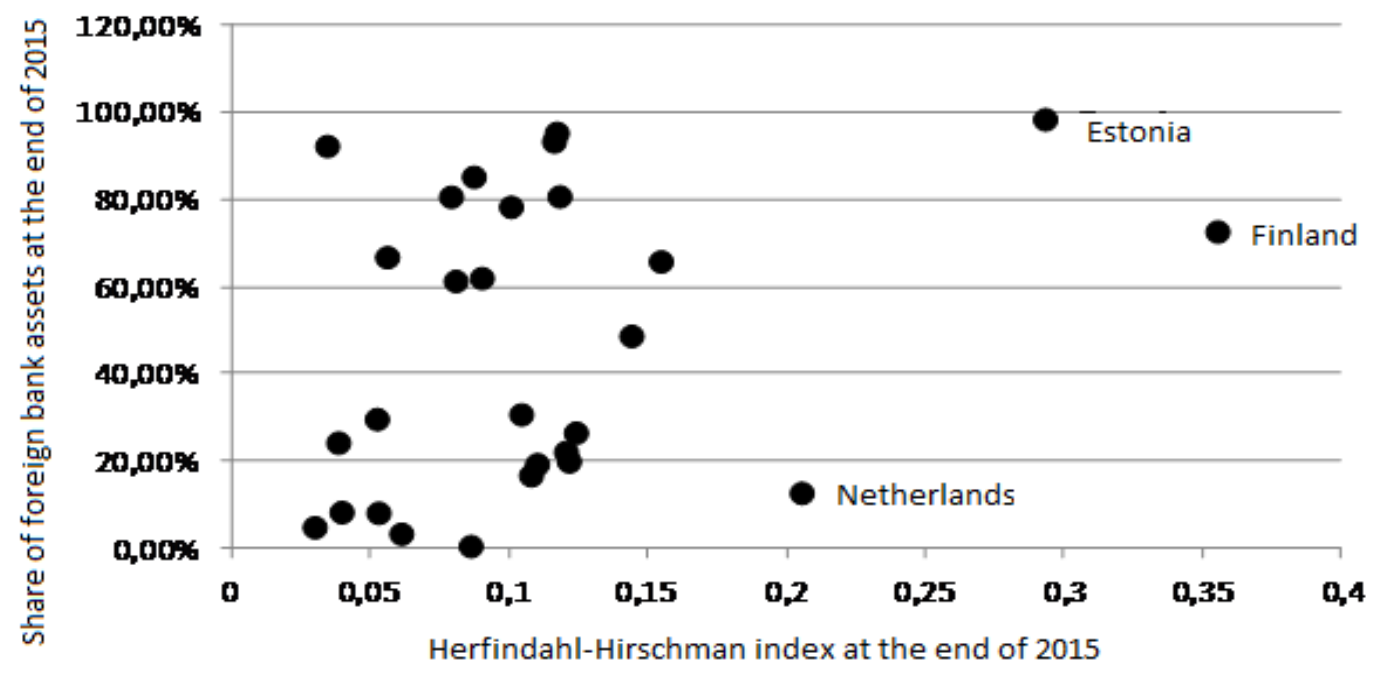

Figure 2. The relationship between the concentration of assets and the share of assets of foreign banks in Europe

Source: compiled by the authors.

From Figure 2 we can conclude that the capture of the banking market by non-resident banks not always leads to an increase in the concentration of assets, at least in Europe.

This can be explained as follows: in countries where the market of banking services with a small number of people or its underdevelopment, the expansion of foreign capital will lead to a rapid concentration of assets, since, as a rule, such expansion will be carried out by a small number of large international banks. In developed countries, or in countries where there is a high potential for development, there will be high competition between non-resident banks themselves, which will seek to seize this market, which means that this will not affect the overall level of concentration of assets. In addition to the above analysis, we also conducted a regression analysis of the impact of foreign capital on concentration in the banking sector. The analysis period covered 2009-2015. The HerfindahlHirschman index was used as the dependent variable, and the share of assets of foreign banks in the total assets of the banking system as an independent variable. It should be noted that according to the methodology of the World Bank, foreign banks include banks in which more than $50 \%$ of the authorized capital belongs to non-residents [3]. The dependencies obtained are shown in Table 2 (see in Appendix).

The search for polynomial dependencies did not justify itself because of the low level of reliability of the approximation and a small number of observations. Thus, we can testify to the presence of linear functional influence of foreign banks on the concentration in the banking sector in countries such as Austria, Belgium, the United Kingdom, Greece, Estonia, Ireland, Italy, Lithuania, Netherlands, Poland, Romania and Slovenia. Another factor that, in our opinion, can characterize competition in the banking sector of the country, is the interest margin of banks. According to some researchers [4], in the banking sector with a high level of competition, interest margin will be low, this is because during the competition, banks will seek to maintain or increase their market share, while yielding their profits in the form of interest . Having checked this hypothesis with the calculation of the correlation between the interest margin and the Herfindahl-Hirschman index for the assets of banks in European countries, we obtained somewhat contradictory results (Table 3, see in Appendix).

Thus, it is possible to identify 6 countries with a strong positive link (correlation coefficient greater than 0.7), these are countries such as Great Britain, Ireland, Luxembourg, Slovakia, Slovenia and Hungary. At the same time, these countries are characterized by the size of the interest margin at the level of the average for European countries (with the exception of Slovakia, where the interest margin is almost 2 times higher than the average).

In addition, there are 7 countries with a strong negative connection, such countries as Bulgaria, Estonia, Spain, Italy, Poland, Portugal and Sweden. At the same time, in these countries, the interest margin is both higher and lower than the average for European countries (Figure 3). 


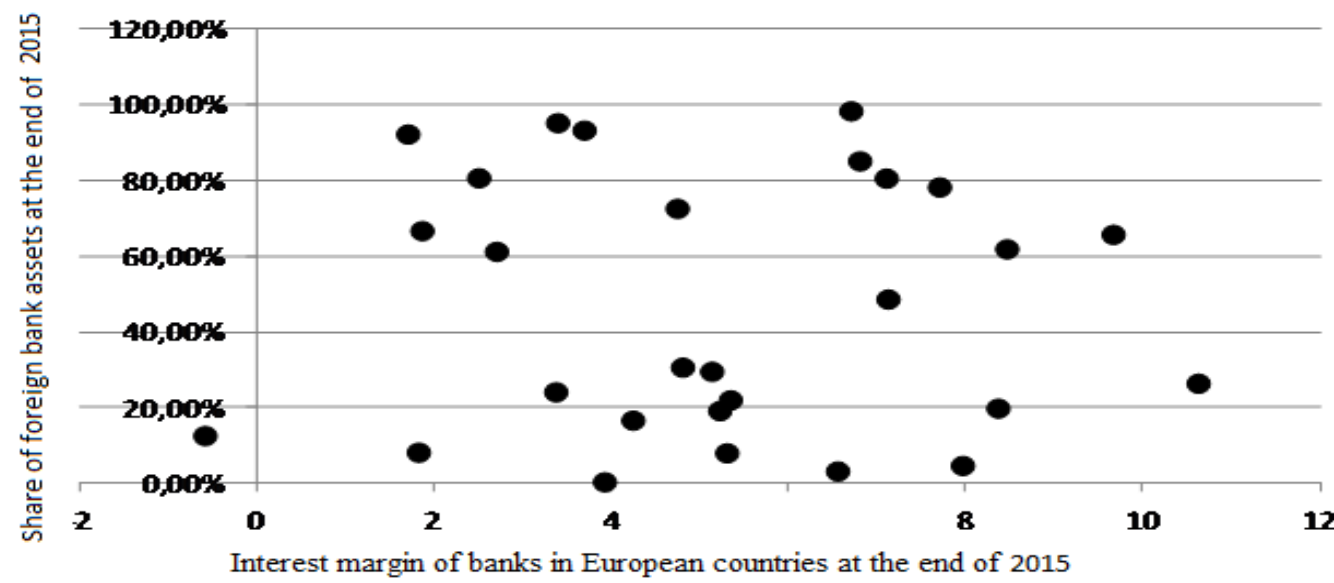

Figure 3. Relativity between the interest margin and the share of assets of foreign banks in Europe

Source: compiled by the authors.

Thus, we can conclude that there is no clear direct relationship between the level of interest margin and the degree of concentration of assets in the banking system of the country for all, which is confirmed by Figure 4. The presence of sufficiently strong correlation links indicates the influence of other factors that enhance the investigated bonds. As you can see, in this case, stable dependency zones can not be detected either. Among other factors, which can affect the level of foreign capital in the banking system, we can distinguish the country's foreign trade turnover. First of all, foreign capital, integrating into the banking system, is aimed at ensuring the interests of companies from the country of the parent bank that carry out export-import operations with companies of the recipient country of banking capital. We can assume that the more foreign trade turnover of the country - the greater the share of foreign capital in its banking system.

In general, the countries of Europe were divided almost equally with the level of foreign trade turnover of more than $100 \%$ of GDP and less than 100\% of GDP. At the same time, in general, the ratio of foreign trade turnover to GDP for the last 8 years has increased from $70.26 \%$ to $85.65 \%$. The highest values are observed in such countries as Luxembourg, Malta, Estonia, Ireland, Hungary and Slovakia (more than 175\%), the least - in Greece, Italy, France, Great Britain and Spain (less than 70\%) (Figure 4).

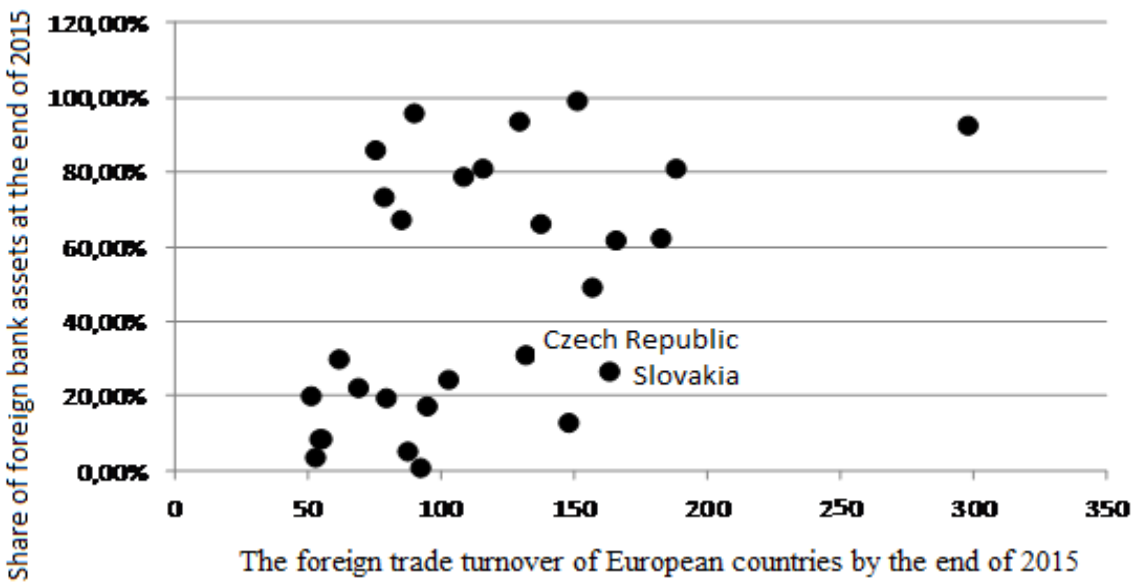

Figure 4. Relativity between foreign trade turnover and the share of assets of foreign banks in European countries

In this case, we can only state a general trend - the growth of foreign trade in the overwhelming majority leads to an increase in the assets of banks with foreign capital, but it is impossible to make an unambiguous distribution. A separate small group is formed by countries with small volumes of foreign trade turnover and low specific gravity of assets of foreign banks, mainly with the exception of Greece, these are powerful developed countries, which, as we defined earlier, are donors of bank capital to other countries. The recipient countries in this case are rather chaotic. Let's summarize the relationships between the factors we are considering and the share of assets of foreign banks in the banking sector of the country, calculating the corresponding correlation coefficients (Table 4). 
Table 4. Correlation coefficients of the influence of the level of foreign capital in the banking system on the indicators of interbank competition and activity in the countries of Europe for the period 2009-2015

\begin{tabular}{|c|c|c|c|}
\hline Country & $H H I / F C$ & $F T T / F C$ & $I M / F C$ \\
\hline Austria & $57.37 \%$ & $91.27 \%$ & $38.80 \%$ \\
\hline Belgium & $-92.02 \%$ & $-43.99 \%$ & $-14.25 \%$ \\
\hline Bulgaria & $95.61 \%$ & $-49.64 \%$ & $-80.16 \%$ \\
\hline United Kingdom & $93.88 \%$ & $-22.09 \%$ & $80.75 \%$ \\
\hline Greece & $-74.97 \%$ & $-78.32 \%$ & $59.58 \%$ \\
\hline Denmark & $-82.43 \%$ & $-84.82 \%$ & $-29.37 \%$ \\
\hline Estonia & $98.69 \%$ & $43.44 \%$ & $-79.33 \%$ \\
\hline Ireland & $42.81 \%$ & $14.51 \%$ & $49.85 \%$ \\
\hline Spain & $-93.43 \%$ & $-19.88 \%$ & $76.83 \%$ \\
\hline Italy & $-23.97 \%$ & $-9.26 \%$ & $-28.50 \%$ \\
\hline Cyprus & $69.54 \%$ & $-68.52 \%$ & $97.85 \%$ \\
\hline Latvia & $96.05 \%$ & $41.80 \%$ & $-46.00 \%$ \\
\hline Lithuania & $-45.40 \%$ & $-2.60 \%$ & $93.85 \%$ \\
\hline Luxembourg & $87.40 \%$ & $-49.14 \%$ & $80.33 \%$ \\
\hline Malta & $-36.50 \%$ & $71.52 \%$ & $70.47 \%$ \\
\hline Netherlands & $-83.23 \%$ & $28.29 \%$ & $68.23 \%$ \\
\hline Germany & $-6.50 \%$ & $-43.85 \%$ & $38.00 \%$ \\
\hline Poland & $-17.35 \%$ & $-11.03 \%$ & $47.33 \%$ \\
\hline Portugal & $-10.45 \%$ & $39.68 \%$ & $-4.64 \%$ \\
\hline Romania & $46.24 \%$ & $-16.94 \%$ & $-31.62 \%$ \\
\hline Slovakia & $56.74 \%$ & $73.64 \%$ & $82.76 \%$ \\
\hline Slovenia & $6.40 \%$ & $-40.00 \%$ & $-4.41 \%$ \\
\hline Hungary & $-86.82 \%$ & $92.30 \%$ & $-85.57 \%$ \\
\hline Finland & $99.16 \%$ & $61.38 \%$ & $-60.52 \%$ \\
\hline France & $63.56 \%$ & $-14.55 \%$ & $11.92 \%$ \\
\hline Czech Republic & $31.96 \%$ & $-30.15 \%$ & $-90.78 \%$ \\
\hline Sweden & $5.31 \%$ & $89.49 \%$ & $-4.79 \%$ \\
\hline European Union (27 countries) & $-95.23 \%$ & $-75.27 \%$ & $60.35 \%$ \\
\hline
\end{tabular}

Notes: FC - Share of foreign capital in the banking system; HHI - Herfindahl-Hirschman index; FTT - Foreign trade turnover; IM Interest margin of banks.

According to the results of our study, we can distinguish separate groups of countries with a significant dependence between the share of foreign capital in the banking system, the Herfindahl-Hirschman index, the foreign trade turnover and the interest margin of banks in Europe (Table 5).

Table 5. European countries with a significant correlation between the share of foreign capital in the banking sector, $\mathrm{HHI}$ index, the interest margin and foreign trade turnover

\begin{tabular}{|c|c|c|c|c|c|}
\hline \multicolumn{7}{|c|}{ Countries with high values of correlation coefficients } \\
\hline \multicolumn{2}{|c|}{$H H I / F C$} & \multicolumn{2}{c|}{$F T T / F C$} & \multicolumn{2}{c|}{$I M / F C$} \\
\hline Bulgaria & Belgium & Austria & Greece & United Kingdom & Bulgaria \\
\hline United Kingdom & Greece & Malta & Denmark & Spain & Estonia \\
\hline Estonia & Denmark & Slovakia & & Cyprus & Hungary \\
\hline Latvia & Spain & Hungary & & Lithuania & Czech Republic \\
\hline Luxembourg & Netherlands & Sweden & & Luxembourg & \\
\hline Finland & Hungary & & & Malta & \\
\hline
\end{tabular}

Notes: FC - Share of foreign capital in the banking system; HHI - Herfindahl-Hirschman index; FTT - Foreign trade turnover; IM Interest margin of banks. 
From the above, we can draw the following conclusion that in the countries of eastern europe, the expansion of foreign capital causes significant changes in the competitive environment of the banking sector (especially in countries such as Hungary, the Czech Republic, Slovakia, Bulgaria, Estonia and Latvia), with the following trend in countries of Europe - the longer the capital movement in the banking sector of the country is liberalized, the less the influence of expansion of foreign capital on competition.

So, we failed to confirm the hypothesis put forward by us, about the existence of a clear relationship between the foreign economic activity of the country and the expansion of foreign capital into the banking system, although in some countries, rather high correlations between the studied indicators were obtained. Regression analysis of the relationship between the concentration of assets and the share of assets of foreign banks did not reveal an unambiguous stable relationship between these indicators, but this can be explained by the short study period (6 years) and the peculiarity of the eu itself, in which quite specific economic ties have formed, economic, political and other interrelations between its members.

\section{Conclusions and recommendations}

The article explores the specific features of the functioning of foreign banking capital in the markets of the countries of the European Union. In general, the share of assets of banks with foreign capital in the total assets of banking systems of the European countries is insignificant - 19.17\%. At the same time, it is established in the work that among 27 countries of the EU it is possible to distinguish two stable aggregates of countries in whose banking systems in 2001-2011. The share of foreign bank capital is practically unchanged. The first group consists of 9 foreign donor countries (Austria, Germany, Portugal, Sweden, Italy, Spain, Greece, Denmark, Cyprus), where the average share of assets of banks with foreign capital in the assets of the banking system is $12.98 \%$. The second group consists of 13 recipient countries of foreign capital (Bulgaria, Estonia, Ireland, Latvia, Lithuania, Luxembourg, Malta, Poland, Romania, Slovenia, Hungary, Finland, the Czech Republic), where the average share of banks with foreign capital in banking assets systems is $71.77 \%$. The authors of the article assert that the markets of the european union countries - recipients of foreign banking capital - are exhausted from the point of view of further growth of the presence of foreign capital on them. The countries of the european union (donors of foreign bank capital) will continue to focus on the markets of new countries.

Regression analysis conducted to formalize the influence of the share of assets of foreign banks and banks under the control of a foreign investor in the assets of banking systems of 27 countries in the EU on the level of competition (measured by the Herfindahl-Hirschman index) allows us to state that there is no single, clearly defined trend: in 9 countries, growth foreign bank capital reduces the concentration of assets (increases the level of competition); in 11 countries - on the contrary; for 11 countries, the dependencies turned out to be inadequate. Correlation analysis of the influence of the level of foreign banking on the indicators of interbank competition (Herfindahl-Hirschman Index, interest margin, etc.) also confirmed the multidirectionality of this influence.

\section{References}

1. Kozmenko, S., Vasilyeva, T., Leonov, S. (2010). Peculiarities of price formation in the banking business of Ukraine. In the monograph: 30 jahre Fachhochschule der Deutschen Bundesbank, Under the editorship of Dr. h.c. Rudolf Bohmler (Hrsg.), Frankfurt am Maine, Diese Sonderveroffentlichung erscheint im Selbstverlag der Deutschen Bundesbank, p. 193-215.

2. Ofitsiynyy veb-sayt Svitovoho banku [Official website of the World Bank]. Retrieved from http://data.worldbank.org/.

3. Nitsenko, V., Cherneha, I. (2011). Rol' inozemnoho kapitalu u rozvytok bankivs'koho sektoru Ukrayiny [The role of foreign capital in the development of the banking sector of Ukraine. Naukovyy klub «SOPHUS». Retrieved from http://sophus.at.ua.

4. Demirguc-Kunt, A., Levine, R., Min, H.-C. (1998). Opening to Foreign Banks. Issues of Stability, Efficiency, and Growth. The Implications of Globalization of World Financial Markets. Bank of Korea, Seoul.

5. Mathieson, D. J., Roldos, J. (2001). The Role of Foreign Banks in Emerging Markets. The third Annual Financial Markets and Development Conference in New York, in April.

6. Morgan, D., Strahan, P. (2003). Foreign Bank Entry and Business Volatility: Evidence from U.S. States and Other Countries. NBER Working Paper, № 9710. 
7. Peria, M., Soledad, M., Mody, A. (2004). How foreign participation and market concentration impact bank spreads: Evidence from Latin America. Journal of Money, Credit, and Banking, 36, 511-537.

8. Schulz, H. (2004). Foreign banks in Mexico: new conquistadors or agents of change? University of Pennsylvania.

9. Pomerleano, M., Vojta, G. What Do Foreign Banks Do in Emerging Markets? [Electronic resource]. The World Bank. Retrieved from: http://www1.worldbank.org/finance/assets/images/Pomerleano_Vojta_presentation.pdf.

10. Paterson, K. (2009). Mexico's Other Crisis: Foreign Banks. Holding Corporations Accountable. Retrieved from http://www.corpwatch.org/article.php?id=15356.

\section{Appendix}

Table 2. Functional dependencies of concentration in the banking system on the share of assets of foreign banks in total assets of the banking system in Europe

\begin{tabular}{|c|c|c|c|}
\hline Country & Functional dependence & $\begin{array}{c}\text { Reliability of } \\
\text { approximation }\left(R^{2}\right)\end{array}$ & $\begin{array}{l}\text { Coefficient of } \\
\text { variation } H H I\end{array}$ \\
\hline Austria & $Y=-0.003 x+0.061$ & 0.902 & $14.59 \%$ \\
\hline Belgium & $Y=-0.011 x+0.234$ & 0.817 & $14.08 \%$ \\
\hline Bulgaria & $Y=0.002 x+0.068$ & 0.549 & $8.42 \%$ \\
\hline UK & $Y=0.002 x+0.034$ & 0.798 & $11.85 \%$ \\
\hline Greece & $Y=0.002 x+0.103$ & 0.894 & $4.89 \%$ \\
\hline Denmark & $Y=-0.0001 x+0.114$ & 0.059 & $5.52 \%$ \\
\hline Estonia & $Y=-0.018 x+0.418$ & 0.919 & $12.28 \%$ \\
\hline Ireland & $Y=0.006 x+0.048$ & 0.903 & $18.94 \%$ \\
\hline Spain & $Y=0.0001 x+0.045$ & 0.387 & $5.94 \%$ \\
\hline Italy & $Y=0.002 x+0.018$ & 0.740 & $22.44 \%$ \\
\hline Cyprus & $Y=0.002 x+0.094$ & 0.694 & $6.78 \%$ \\
\hline Latvia & $Y=-0.0001 x+0.116$ & 0.006 & $8.50 \%$ \\
\hline Lithuania & $Y=-0.005 x+0.197$ & 0.753 & $7.11 \%$ \\
\hline Luxembourg & $Y=-0.0001 x+0.036$ & 0.429 & $7.98 \%$ \\
\hline Netherlands & $Y=0.006 x+0.167$ & 0.752 & $8.27 \%$ \\
\hline Germany & $Y=0.001 x+0.013$ & 0.585 & $21.90 \%$ \\
\hline Poland & $Y=-0.002 x+0.069$ & 0.794 & $8.33 \%$ \\
\hline Portugal & $Y=0.001 x+0.109$ & 0.370 & $3.37 \%$ \\
\hline Romania & $Y=-0.005 x+0.122$ & 0.808 & $12.55 \%$ \\
\hline Slovakia & $Y=0.002 x+0.106$ & 0.533 & $6.49 \%$ \\
\hline Slovenia & $Y=-0.003 x+0.144$ & 0.920 & $6.54 \%$ \\
\hline Hungary & $Y=0.0001 x+0.079$ & 0.244 & $3.00 \%$ \\
\hline Finland & $Y=0.014 x+0.233$ & 0.660 & $13.04 \%$ \\
\hline France & $Y=-0.001 x+0.071$ & 0.234 & $7.87 \%$ \\
\hline Czech Republic & $Y=-0.001 x+0.115$ & 0.632 & $4.67 \%$ \\
\hline Sweden & $Y=0.000 x+0.085$ & 0.158 & $4.89 \%$ \\
\hline European Union (27 countries) & $Y=-0.0001 x+0.112$ & 0.332 & $1.03 \%$ \\
\hline
\end{tabular}


Table 3. The correlation coefficient between the interest margin and the Herfindahl-Hirschman index for the assets of European banks during 2009-2015

\begin{tabular}{|c|c|}
\hline Country & Coefficient of variation: $I M / H H I$ \\
\hline Austria & -0.08 \\
\hline Belgium & -0.09 \\
\hline Bulgaria & -0.86 \\
\hline United Kingdom & 0.92 \\
\hline Greece & -0.67 \\
\hline Denmark & 0.14 \\
\hline Estonia & -0.88 \\
\hline Ireland & 0.85 \\
\hline Spain & -0.73 \\
\hline Italy & -0.83 \\
\hline Cyprus & 0.54 \\
\hline Latvia & -0.42 \\
\hline Lithuania & -0.62 \\
\hline Luxembourg & 0.97 \\
\hline Malta & 0.23 \\
\hline Netherlands & -0.27 \\
\hline Germany & 0.37 \\
\hline Poland & -0.87 \\
\hline Portugal & -0.76 \\
\hline Romania & 0.40 \\
\hline Slovakia & 0.92 \\
\hline Slovenia & 0.97 \\
\hline Hungary & 0.71 \\
\hline Finland & -0.61 \\
\hline France & -0.25 \\
\hline Czech Republic & -0.54 \\
\hline Sweden & -0.99 \\
\hline European Union (27 countries) & -0.38 \\
\hline
\end{tabular}

Notes: $H H I$ - Herfindahl-Hirschman index, $I M$ - Interest margin of banks. 